\title{
ANALISIS KUALITAS KESADARAN MEREK, ASOSIASI MEREK, DAN LOYALITAS KONSUMEN MI INSTAN
}

\author{
Yohanes Billy Somantri \\ Leonita Martha Atmadjaja \\ Universitas Katolik Parahyangan \\ Universitas Widyatama \\ Email:beely.jhon@gmail.com; leonitamartha@gmail.com
}

Submitted: Mar 6, 2018; Reviewed: Mar 12, 2018; Accepted: May 25, 2018

\begin{abstract}
In this study the respondents involved are consumers who make a purchase at one of Supermarket in Bandung. The goal of the study was to show brand awareness, quality perceptions, brand associations and brand loyalty that ultimately affect the purchase decision of instant noodles at the supermarket. The results of the study showed that brand awareness, perceived quality, brand association and brand loyalty has affect simultaneously in making the decision of purchasing. The conclusion of the study showed that instant noodles that are not top brand such as sarimi, has brand equity like instant noodle of the top brand.
\end{abstract}

Keywords: Brand Awareness; Brand Equity Brand Loyalty, Perceived Quality; Purchasing Decision

\section{PENDAHULUAN}

Dunia usaha di Indonesia saat ini dihadapkan pada keadaan persaingan yang sangat ketat. Perkembangan di era globalisasi masa sekarang ini telah mengubah pandangan kehidupan yang lebih instant, dinamis dan selalu mengedepankan efektifitas dan efisiensi dalam segala aktivitas sehari-hari. Hal ini tidak terkecuali dengan perkembangan kebutuhan manusia yang beraneka ragam maka setiap orang dituntut untuk dapat memenuhi kebutuhan hidupnya masingmasing dengan bagaimanapun caranya, khususnya pada masyarakat perkotaan. Maka dari itu, banyak pengusaha pun yang dituntut untuk dapat memutar terus roda usahanya guna membantu manusia memenuhi kebutuhan hidupnya yang semakin instant, efektif, dan efisien. Saat ini persaingan perusahaan dalam pemasaran tidak terbatas hanya pada atribut fungsional produk saja misalnya seperti kegunaan produk, melainkan sudah dikaitkan dengan merek yang mampu memberikan citra khusus bagi penggunanya. Produk menjelaskan sebagai komoditi yang dipertukarkan, sedangkan merek menjelaskan pada spesifikasi pelanggannya. Merek (brand) adalah salah satu faktor penting dalam kegiatan pemasaran. Berdasarkan UU Merek No.15 Tahun2001 pasal 1 ayat 1 , merek adalah tanda yang berupa gambar, nama, kata huruf-huruf, angka-angka, susunan warna, atau kombinasi dari unsur-unsur tersebut yang memiliki daya pembeda dan digunakan dalam kegiatan perdagangan barang atau jasa.

Dari perspektif diatas maka dapat diambil kesimpulan bahwa merek pada dasarnya mengandung nilai-nilai potensial sebagai sumber keunggulan kompetitifyang sangat strategis bagi perusahaan dalam menghadapi persaingan bisnis, nilai-nilai ini kemudian oleh banyak pakar didefinisikan sebagai ekuitas merek. Ekuitas merek (brand equity) adalah nilai tambah yang diberikan pada produk dan jasa. Ekuitas merek dapat tercermin dalam cara konsumen berpikir, merasa, dan bertindak dalam hubungannya dengan merek dan juga harga, pangsa pasar, dan profitabilitasnya yang diberikan merek bagi perusahaan. (Kotler, 2010). Menurut David A. Aaker dalam buku Power of Brands (Rangkuti, The Power of Brands Teknik Mengelola Brand Equity dan Strategi Pengembangan Merek, hal. 39) terdapat empat elemen utama pembentuk 
ekuitas merek, antara lain Brand Awareness (Kesadaran Merek) kesanggupan sesorang calon pembeli untuk mengenali atau mengingat kembali bahwa suatu merek merupakan bagian dari kategori produk tertentu; Perceived Quality (Kesan Kualitas) persepsi pelanggan terhadap keseluruhan kualitas atau keunggulan suatu produk atau jasa layanan berkaitan dengan maksud yang diharapkan; Brand Associations (Asosiasi Merek) segala hal yang berkaitan dengan ingatan mengenai merek; Brand Loyalty (Loyalitas Merek) suatu ukuran keterkaitan pelanggan terhadap sebuah merek. Ukuran ini mampu memberikan gambaran tentang kemungkinan seorang pelanggan beralih ke produk lain terutama pada suatu merek tersebut didapati adanya perubahan, baik menyangkut harga atau atribut lain. Ekuitas merek yang dibentuk oleh perusahaan akan mempengaruhi keputusan pembelian dari konsumen. Pengaruh tersebut diawali dari kesadaran merek (brand awareness), dimulai dari calon pembeli mengenal merek dari setiap kebutuhannya dan hal tersebut bersamaan dengan tahapan pertama dan kedua dari keputusan pembelian. Biasanya calon konsumen pada proses ini melihat merek dari iklan-iklan atau dari orang lain. Selanjutnya setelah calon pembeli mengenal merek maka akan berusaha untuk mengetahui informasiterkait dengan merek tersebut dan proses ini berkaitan dengan asosiasi merek (brand associations). Setelah kedua proses tersebut dimensi dari ekuitas merek yang akan berpengaruh terhadap keputusan pembelian adalah persepsi kualitas (perceived quality) yang mana seorang calon konsumen akan mulai yakin terhadap merek yang dipilih sesuai dengan kebutuhannya dan mulai melakukan pembelian serta mengkonsumsi produk dari merek tersebut. Pada proses inilah pembeli mulai memproses dan menyesuaikan antara kebutuhannya dengan merek yang dipilih. Proses selanjutnya adalah bagaimana seorang konsumen memiliki loyalitas terhadap merek tersebut dan pada proses ini yang berperan adalah loyalitas merek (brand loyalty). Proses yang terakhir ini terlihat bahwa ekuitas merek yang kuat akan sangat berpengaruh terhadap keputusan pembelian konsumen, karena bila ekuitas merek tersebut tertanam dengan kuat maka konsumen akan sulit berpindah ke merek lain.

Tahapan tersebut adalah proses bagaimana ekuitas merek sangat berpengaruh terhadap keputusan pembelian yang akan dilakukan oleh seorang calon konsumen. Keputusan pembelian merupakan tahap-tahap yang dilalui konsumen dalam menentukan pilihan tentang produk dan jasa yang akan dibeli atau tidak (Kotler, 2010). Pengambilan keputusan sendiri merupakan sebuah proses yang terdiri dari beberapa tahapan yaitu pengenalan kebutuhan, pencarian informasi, evaluasi alternatif sebelum pembelian, pembelian, konsumsi dan evaluasi alternatif sesudah pembelian. Selain itu dalam keputusan pembelian dipengaruhi juga oleh beberapa faktor baik itu yang berasal dari dalam diri konsumen maupun dari dalam diri konsumen itu sendiri. Menurut (Kotler, 2010) beberapa faktor yang dapat mempengaruhi konsumen diantaranya faktor budaya, pribadi, sosial dan psikologis. Salah satu dari faktor tersebut akan memberikan pengaruh yang lebih besar dari pengaruh lain.

Salah satu usaha yang dituntut untuk membantu memenuhi kebutuhan manusia pada saat ini yang bersifat instant, efektif dan efisien adalah usaha di bidang pangan/kuliner. Setiap orang pasti membutuhkan makanan dan minuman sesibuk apapun keadaannya. Banyak pengusaha di bidang kuliner yang saat ini bersaing untuk memberikan atau menyajikan kuliner yang berbeda dari yang lainnya agar calon pelanggan tertarik untuk membeli. Berbagai macam pilihan disajikan oleh para produsen ini tentunya membuat para calon pelanggan bingung dan memikirkan berbagai macam faktor pertimbangan sampai pada akhirnya memutuskan untuk melakukan pembelian produk tersebut. Namun pada akhirnya pasti akan ada satu merek yang lebih unggul dibanding yang lainnya karena merek tersebut mempunyai nilai tambah atau kekuatan tersendiri di mata pelanggan, sebut saja merek tersebut unggul dalam hal harga, kualitas, distribusi, varian produk, dan masih banyak lagi.

Berbagai macam cara dilakukan pengusaha kuliner agar mampu bersaing secara ketat, baik itu dari sisi harga, sisi kreativitas dalam membuat konsep usaha, konsep menu makanan dan minuman, dan lain-lain. Namun, selain memperhatikan konsep dari menu makanan-minuman ataupun dari sisi harga, agar dapat bertahan dan tetap terus berkembang pengusaha 
kuliner juga perlu memperhatikan dan mempelajari perilaku konsumen dalam memilih dan memutuskan untuk membeli makanan-minuman tersebut. Konsumen saat ini selain menginginkan makanan dan minuman yang enak dan harga yang murah meriah, mereka juga menginginkan makanan-minuman yang mereka konsumsi bisa didapatkan secara cepat, instant dan efektif untuk mereka sehingga waktu yang mereka miliki pun lebih banyak untuk melakukan aktivitas lainnya. Keadaan yang sibuk dan waktu terbatas yang menuntut mereka untuk memiliki jam makan yang singkat.

Salah satu produk makanan yang memberikan kemudahan untuk didapatkan, instant untuk diprosesnya, efektif dan efisien bagi konsumen adalah produk mie instant. Mie instant sekarang ini sudah bisa didapatkan dimana saja, mulai dari warung hingga supermarket pasti ada. Mie instant saat ini tersedia dengan berbagai macam rasa, berbagai macam merek, dan berbagai macam bentuk kemasan yang dapat dipilih oleh konsumen. Di Indonesia, mie instant seringkali dijadikan sebagai makanan pengganti nasi karena jenis makanan ini murah dan mudah ditemukan dimana-mana. Penduduk Indonesia merupakan penduduk yang rata-rata mengkonsumsi makanan pokok lebih dari satu jenis atau variatif. Di Indonesia terdapat 4 jenis makanan pokok, yaitu nasi, sagu, ubi, dan terakhir mie. Menurut sumber World Instant Noodle Association (WINA) 2015 Indonesia menempati urutan ke-2 sebagai negara yang penduduknya gemar mengkonsumsi mie instant setelah negara China. Fakta tersebut bisa diartikan bahwa mie instant bisa menjadi makanan pengganti makanan pokok bagi beberapa orang. Berikut tabel permintaan sekaligus tingkat konsumsi mie instant di dunia:

Tabel 1 Permintaan Mie Instant di Dunia

\begin{tabular}{llrrrrr}
\hline & Country / Region & 2010 & 2011 & 2012 & 2013 & 2014 \\
\hline 1 & China / Hong Kong & 42300 & 42470 & 44030 & 46220 & 44400 \\
2 & Indonesia & 14400 & 14530 & 14750 & 14900 & 13430 \\
3 & Japan & 5290 & 5510 & 5410 & 5520 & 5500 \\
4 & India & 2940 & 3530 & 4360 & 4980 & 5340 \\
5 & Viet Nam & 4820 & 4900 & 5060 & 5200 & 5000 \\
6 & USA & 4180 & 4270 & 4340 & 4350 & 4280 \\
7 & Republic of Korea & 3410 & 3590 & 3520 & 3630 & 3590 \\
8 & Thailand & 27100 & 2880 & 2960 & 3020 & 3070 \\
9 & Philippines & 2700 & 2840 & 2720 & 2720 & 2800 \\
10 & Brazil & 2000 & 2140 & 2320 & 2480 & 2360 \\
11 & Russia & 1900 & 2060 & 2090 & 2120 & 1940 \\
12 & Nigeria & 1180 & 1260 & 1340 & 1430 & 1520 \\
13 & Malaysia & 1220 & 1320 & 1300 & 1350 & 1340
\end{tabular}

\begin{tabular}{|c|c|c|c|c|c|c|}
\hline 14 & Nepal & 730 & 820 & 890 & 1020 & 1110 \\
\hline 15 & Mexico & 830 & 850 & 890 & 920 & 890 \\
\hline 16 & Taiwan & 780 & 760 & 780 & 750 & 710 \\
\hline 17 & Saudi Arabia & 590 & 620 & 640 & 660 & 690 \\
\hline 18 & Ukraine & 540 & 540 & 560 & 580 & 580 \\
\hline 19 & Myanmar & 240 & 240 & 300 & 340 & 410 \\
\hline 20 & UK & 320 & 340 & 350 & 370 & 380 \\
\hline 21 & Australia & 340 & 340 & 350 & 3540 & 360 \\
\hline 22 & Poland & 300 & 290 & 270 & 260 & 300 \\
\hline 23 & Cambodia & 330 & 260 & 260 & 240 & 250 \\
\hline 24 & Bangladesh & 90 & 100 & 160 & 220 & 250 \\
\hline 25 & Egypt & 100 & 120 & 150 & 170 & 200 \\
\hline 26 & Canada & 210 & 210 & 210 & 210 & 190 \\
\hline 27 & South Africa & 140 & 150 & 170 & 170 & 190 \\
\hline 28 & Germany & 180 & 180 & 180 & 180 & 180 \\
\hline 29 & Peru & 50 & 60 & 70 & 80 & 170 \\
\hline 30 & Pakistan & 110 & 120 & 130 & 130 & 150 \\
\hline 31 & Guatemala & N/A & $\mathrm{N} / \mathrm{A}$ & $\mathrm{N} / \mathrm{A}$ & 80 & 150 \\
\hline 32 & Kazakhstan & 120 & 130 & 130 & 140 & 140 \\
\hline 33 & Singapore & 120 & 120 & 130 & 130 & 130 \\
\hline 34 & Uzbekistan & 100 & 100 & 110 & 110 & 110 \\
\hline 35 & Czech Republic & 90 & 100 & 90 & 90 & 90 \\
\hline 36 & New Zeland & 70 & 70 & 80 & 70 & 80 \\
\hline 37 & France & 40 & 50 & 50 & 60 & 60 \\
\hline 38 & Chile & 10 & 20 & 20 & 30 & 40 \\
\hline 39 & Sweden & 0 & 20 & 20 & 30 & 30 \\
\hline 40 & Denmark & 20 & 20 & 20 & 20 & 20 \\
\hline 41 & Hungary & 20 & 20 & 20 & 20 & 20 \\
\hline 42 & Netherlands & 20 & 20 & 20 & 20 & 20 \\
\hline 43 & Finland & 20 & 20 & 20 & 20 & 10 \\
\hline \multirow[t]{2}{*}{-} & Others & 310 & 220 & 230 & 250 & 270 \\
\hline & Total & 95870 & 98200 & 101490 & 105650 & 102740 \\
\hline
\end{tabular}

Sumber:

http://databoks.katadata.co.id/datapublish/2017/01/30/ indofood-kuasai-71-pasar-mi-instant-indonesia

Produsen yang melihat hasil permintaan akan mie instant ini menjadikan sebuah peluang bisnis yang sangat menjanjikan untuk memberikan keuntungan yang optimal. Berdasarkan Tabel 1.1 di atas, walaupun di Indonesia sempat mengalami penuruan permintaan mie instant pada tahun 2014 namun tetap membuat negara Indonesia berada di peringkat ke-2 setelah China. Hal ini tentu saja didukung oleh banyaknya produsen mie instant di Indonesia yang bermunculan dan terus berinovasi untuk bersaing menguasai pangsa pasar mie instant. Berikut adalah data penguasaan pangsa pasar mie instant di Indonesia pada tahun 2016:
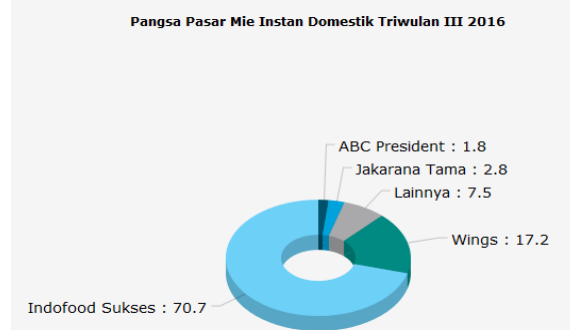

Gambar 1 Pangsa Pasar Mie Instant Domestik Triwulan III 2016

Sumber:

http://databoks.katadata.co.id/datapublish/2017/01/30/ indofood-kuasai-71-pasar-mi-instant-indonesia 
Dapat dilihat bahwa PT. Indofood CBP Sukses Makmur Tbk. menguasai lebih dari setengah pangsa pasar mie instant di Indonesia sebesar 70.7\% dan disusul oleh Wings Food yang menjadi saingan terberatnya dari tahun 2003 sampai saat ini dalam persaingan pasar mie instant yaitu sebesar 17,2\%. Berdasarkan data di atas MieInstant merupakan Fenomena salah satu makanan yang banyak diminati oleh pasar. Melalui persaingan penguasaan pangsa pasar mie instant ini membuat begitu banyak produk mie instant bermunculan di pasar Indonesia dengan berbagai macam merek, harga, varian rasa, ukuran, dan lain-lain. Merek mie instant yang sudah tidak asing lagi bagi kita, antara lain sebut saja merek Indomie , Sarimi, Supermi, Salam Mie, Mie Sedaap, Sarimi, Mi ABC, Gaga Mie, dan masih banyak lagi lengkap dengan merekmerek mie instant yang di ekspor luar negeri yang secara otomatis menjadi kompetitor produk mie instant lokal. Namun dari semua merek mie instant yang ada di Indonesia ternyata ada beberapa top brand mie instant yang menjadi pilihan konsumen. Berikut hasil survei tahun 2016 menurut Top Brand Award tahun 2016:

Tabel 2 Top Brand Award Indonesia

\begin{tabular}{ccc}
\hline \multicolumn{3}{c}{ Mie Instant Dalam Kemasan Bag } \\
\hline Merek & TBI & TOP \\
Indomie & $78.7 \%$ & TOP \\
Mie Sedaap & $12.5 \%$ & TOP \\
Sarimi & $3.6 \%$ & \\
Supermi & $3.0 \%$ & \\
\hline
\end{tabular}

Sumber:http://www.topbrand-award.com/top-brandsurvey/survey-result/top_brand_index_2016_fase_1

Berdasarkan hasil survei Top Brand Award tahun 2016 fase 1 dengan kategori mie instant, merek Indomie menjadi top brand di Indonesia dengan tingkat konsumsi sebesar $78,7 \%$ dan yang terendah adalah merek Supermie dengan persentase $3.0 \%$. Hal ini juga turut membuktikan bahwa PT. Indofood CBP Sukses Makmur Tbk. memang masih mampu bertahan dalam persaingan menguasai pangsa pasar mie instant di Indonesia hingga saat ini. Berdasarkan data tersebut, dapat dilihat pula jika produk mie instant merek Indomie mendominasi penjualan produk mie instant di Indonesia. Produk Indomie sendiri memang telah menciptakan brand equity yang kuat di pasarnya jika dibandingkan dengan para pesaingnya dan hal ini secara tidak langsung merupakan tantangan tersendiri bagi para pesaing Indomie untuk dapat tetap bertahan dalam industri makanan mie instant dan dipilih pelanggan tentunya.

Selain data penjualan mie instant berdasarkan Top Brand Award tahun 2016 di Indonesia, data penjualan lainnya didukung juga oleh data yang telah penulis dapatkan dari hasil wawancara dengan distributor terbesar khususnya data penjualan di salahsatu Supermarket di Kota Bandung berupa data ranking 5 besar penjulan mie instant, berikut adalah datanya :

Tabel 3 Ranking Penjualan Mie Instant

\begin{tabular}{cc}
\hline Rangking & Merek Mie Instant \\
\hline 1 & Indomie \\
2 & Mie Sedap \\
3 & Sarimi \\
4 & Mie Instant Impor \\
5 & Supermi \\
\hline Sumber: HRD one of Supermarket at Bandung
\end{tabular}

Melalui data ranking penjualan mie instant di Supermarket X Bandung ini menunjukkan jika mie instant merek Indomie kembali menjadi "juara" dalam industri mie instant. Memiliki modal brand equity yang kuat seperti Indomie merupakan keuntungan bagi perusahaan dalam hal pemasaran produk yang tidak perlu terlalu memakan biaya besar dan waktu lagi untuk mengenalkan dan memasarkan produk di pasaran dan secara tidak langsung dapat mempengaruhi keputusan pembelian pelanggan untuk terus melakukan pembelian secara berulang terhadap produk merek tersebut.

Maka dari itu dalam penelitian ini, penulis hendak membahas permasalahan brand equity mie instant merek Sarimi yang kalah saing hasil penjualannya dibandingkan dengan merek Indomie. Sebenarnya merek Sarimi sendiri merupakan mie instant yang sudah memiliki nama atau merek yang cukup dikenal oleh masyarakat dan merupakan hasil produksiPT. Indofood CBP Sukses Makmur Tbk. juga seperti mie instant merek Indomie. Selain itu, fenomena yang penulis dapat lihat juga adalah dari sisi 
pemasarannya yang dilakukan oleh mie instant merek Sarimi. Sarimi dapat dikatakan lebih intens dalam melakukan pemasaran produknya dibandingkan dengan mie instant merek Indomie contohnya saja iklan produk Sarimi yang lebih sering dapat kita jumpai daripada Indomie, namun tetap saja Sarimi mengalami kalah saing dengan Indomie. Tingkat konsumsi dan penjualan mie instant merek Sarimi ini memiliki peresentase yang cukup rendah jika dilihat dari Tabel 2 di atas yaitu $3.6 \%$ dan berada pada ranking ke-3 dalam penjualan di Supermarket X di Kota Bandung. Kekalahan persaingan penjualan mie instant merek Sarimi dengan Indomie ini dikarenakan mie instant Indomie sendiri sudah menjadi top of mind dan memiliki brand equity yang kuat di kalangan masyarakat dalam hal mie instant, maka Indomie sudah tidak perlu lagi melakukan banyak kegiatan pemasaran untuk mengingatkan akan merek serta produknya kepada konsumen di pasaran. Namun dibalik keuntungan dan kelebihan yang dimiliki Indomie tersebut justru hal itu menjadi tuntutan dan tantangan tersendiri bagi mie instant merek lainnya yang perlu berjuang lebih keras untuk bersaing di industri mie instant. Seperti yang dilakukan mie instant Sarimi agar tetap dapat bertahan dalam persaingannya, Sarimi terus melakukan upaya untuk menciptakan brand equity yang kuat di pasaran, misalnya inovasi produk danpemasaran dengan memberikan iklaniklan produk Sarimi secara intens serta promosi produk untuk terus mengingatkan konsumen tentangan keberadaan merek mie instantnya di pasar. Maka dari itu penulis hendak melakukan penelitian dengan judul: "Faktor Brand Equity Merek Sarimi Dari Sisi Brand Awareness, Perceived Quality, Brand Association, dan Brand Loyalty yang Berpengaruh terhadap Keputusan Pembelian.

\section{KAJIAN LITERATUR DAN HIPOTESIS}

Ekuitas merek (Brand Equity) adalah nilai tambah yang diberikan pada produk dan jasa. Ekuitas merek dapat tercermin dalam cara konsumen berpikir, merasa, dan bertindak dalam hubungannya dengan merek dan juga harga, pangsa pasar, dan profitabilitasnya yang diberikan merek bagi perusahaan. (Kotler, 2010).Dalam membentuk ekuitas merek diperlukan elemen-elemen pendukung, menurut David A. Aaker dalam buku Power of Brands(Rangkuti, 2009) terdapat lima elemen pendukung pembentuk ekuitas merek, antara lain Brand Awareness (Kesadaran Merek), Perceived
Quality (Kesan Kualitas), Brand Associations (Asosiasi Merek), Brand Loyalty (Loyalitas Merek) diciptakan."Segala hal yang berkaitan dengan ingatan mengenai merek."Asosiasi itu tidak hanya eksis, namun juga memiliki suatu tingkat kekuatan (Ferrinadewi, 2008).

Peran brand awareness dalam keseluruhan brand equity tergantung dari sejauh mana tingkatan kesadaran yang dicapai oleh suatu merek. Tingkat brand awareness dari tingkat terendah sampai tingkat tertinggi adalah unware of brand (tidak menyadari merek), brand recognition (pengenalan merek), brand recall (pengingatan kembali terhadap merek), dan top of mind (puncak pikiran). Mendefinisikan kesadaran merek adalah kemampuan dari konsumen potensial untuk mengenali atau mengingat bahwa suatu merek termasuk ke dalam kategori produk tertentu. (Handayani dkk., 2010). Indikator untuk mengukur perceived quality didefinisikan sebagai persepsi konsumen terhadap kualitas atau keunggulan suatu produk atau jasa sehubungan dengan tujuan yang diinginkannya, dibandingkan dengan alternatif alternatif lain (Handayani dkk., 2010).

Features, yaitu elemen sekunder dari produk atau bagian tambahan dari produk. Conformance with specifications, yaitu tidak ada produk yang cacat. Reliability, yaitu konsistensi kinerja produk. Durability, yaitu daya tahan sebuah produk. Serviceability, yaitu kemampuan memberikan pelayanan sehubungandengan produk. Fit and finish, yaitu menunjukkan saat munculnya atau dirasakannyakualitas produk.

Pengertian asosiasi merek menurut (Aker, 2009)adalah segala hal yang berkaitan dengan ingatan mengenai merek. Asosiasi itu tidak hanya eksis, namun juga memiliki suatu tingkat kekuatan. Keterkaitan pada suatu merek akan lebih kuat apabila dilandasi pada banyak pengalaman atau penampakan untuk mengkomunikasikan-nya.Berbagai asosiasi yang diingat konsumen dapat dirangkai sehingga membentuk citra tentang merek atau brand image di dalam benak konsumen. Indikator untuk mengukur brand associationMenurut (Palupi, 2009), asosiasi memiliki beberapa tipe, yaitu: Atribut (atributes), yaitu asosiasi yang dikaitkan dengan atribut-atribut dari merek tersebut baik yang berhubungan langsung terhadap produknya (product related atributes), ataupun yang tidak berhubungan langsung terhadap produknya (non product related atribues) yang meliputi price, user imagery, usage imagery, feelings, experiences, dan brand 
personality, manfaat (Benefits), merupakan asosiasi suatu merek yang dikaitkan dengan manfaat dari merek tersebut, baik itu manfaat secara fungsional (functional benefit), manfaat secara simbolik (symbolic benefit), dan pengalaman yang dirasakan penggunanya (experiential benefit), dan perilaku (attitudes), adalah asosiasi yang dikaitkan dengan motivasi diri sendiri yang merupakan bentuk perilaku yang bersumber dari bentuk-bentuk punishment, reward, learning, dan knowledge.

Menurut (Aker, 2009), loyalitas merek memiliki pengertian, yaitu suatu ukuran keterkaitan pelanggan terhadap sebuah merek. Ukuran ini mampu memberikan gambaran tentang kemungkinan seorang pelanggan beralih ke produk lain terutama pada suatu merek tersebut didapati adanya perubahan, baik menyangkut harga atau atribut lain. (Rangkuti, 2009) menjelaskan bahwa loyalitas merek dapat diukur melalui beberapa hal, antara lain: Behaviour Measures, Measuring switch cost, Measuring satisfaction, Measuring liking brand, Measuring commitment.

Pengertian keputusan pembelian menurut (Hermawan, 2009), adalah mengidentifikasikan semua pilihan yang mungkin untuk memecahkan persoalan itu dan menilai pilihan-pilihan secara sistematis dan obyektif serta sasaran-sasarannya yang menentukan keuntungan serta kerugiannya masing-masing, dan menurut (Schiffman \& Kanuk, 2009) keputusan pembelian adalah pemilihan dari dua atau lebih alternatif pilihan keputusan pembelian, artinya bahwa seseorang bisa membuat keputusan, harus tersedia beberapa alternatif pilihan. Keputusan untuk membeli bisa mengarah pada bagaimana proses dalam pengambilan keputusan tersebut itu dilakukan. Keputusan pembelian konsumen dipengaruhi oleh perilaku konsumen. Rasa percaya diri pelanggan atas keputusan pembelian disebabkan karena kedekatan pelanggan dengan merek, baik itu disebabkan oleh pengiklanan dan kepopuleran merek, kredibilitas merek di mata pelanggan, serta pengalaman pelanggan atas merek tersebut (Aker, 2009) adalah benar yang memiliki indikator sebagai berikut kemantapan membeli, pertimbangan dalam membeli, Kesesuaian atribut dengan keinginan dan kebutuhan.

Hal-hal yang menjadi indikator keputusan pembelian, adalah kemantapan membeli, pertimbangan dalam membeli, dan kesesuaian atribut dengan keinginan dan kebutuhan. Berdasarkan penjelasan di atas, makan kerangka pemikiran penulis dapat digambarkan seperti pada Gambar 2.

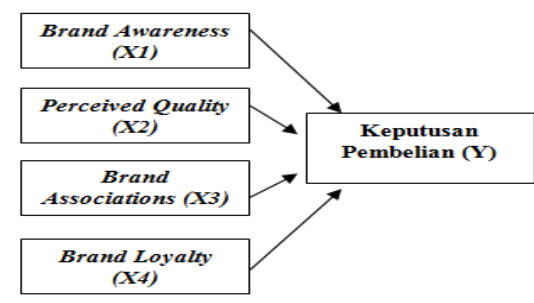

Gambar 2 Paradigma Penelitian dan Hipotesis

Sumber: Diolah dari berbagai sumber

\section{HIPOTESIS}

1. Brand awareness mie instant sangat baik dan dikenal konsumen, perceived quality-nya dinilai sangat bagus, brand association-nya dinilai sangat baik, dan brand loyalty-nya sangat kuat di Supermarket Kota Bandung.

2. Brand awarenessberpengaruh positif terhadap keputusan pembelian.

3. Perceived quality berpengaruh positif terhadap keputusan pembelian.

4. Brand association berpengaruh positif terhadap keputusan pembelian.

5. Brand loyalty berpengaruh positif terhadap keputusan pembelian.

6. Brand awareness, perceived quality, brand association, dan brand loyalty berpengaruh positif secara bersamaan terhadap keputusan pembelian.

\section{METODE PENELITIAN}

Penelitian ini menganalisa mengenai pengaruh brand equity terhadap keputusan pembelian Supermarket X di Kota Bandung. Adapun yang menjadi objek penelitian sebagai variabel bebas /X-independent variable yaitu brand equity yang di dalamnya terdapat faktor brand awareness (kesadaran merek), perceived quality (kesan kualitas), brand associations (asosiasi merek), dan brand loyalty (kesetiaan merek). Sedangkan yang menjadi variabel terikat /Y-dependent variable yaitu keputusan pembelian. Unit analisis dalam penelitian ini adalah konsumen Supermarket $X$ di Kota Bandung. Dalam penelitian ini penulis menggunakan metode penelitian deskriptif-verifikatif, teknik pengambilan sampel yang digunakan dalam penelitian ini adalah menggunakan rumus Malhotra, teknik pengukuran skor atau nilai memakai skala likert,model regresi digunakan untuk menganalisis pengaruh, analisis koefisien 
korelasi,uji hipotesis dengan uji-t,uji-F, koefisien determinasi.

\section{HASIL DAN PEMBAHASAN}

Dari hasil penelitian Brand Awareness (X1), keseluruhan berada dalam kategori baik dengan rata-rata skor jawaban diperoleh sebesar 2,76 artinya responden cukup baik dalam menyadari adanya mie instant merek Sarimi, karena berada pada interval 2,60 - 3,39.Berdasarkan hasil jawaban responden mengenai Brand Awareness, yaitu pernyataan cukup setuju sebanyak $91.30 \%$, tidak setuju $5.80 \%$ dan sangat tidak setuju $2,90 \%$. Dengan bobot rata-rata tertinggi sebesar 2,86 berada pada pernyataan "Pelanggan menyadari adanya mie instant merek Sarimi" dan "Pelanggan dapat langsung mengenali mie instant Sarimi hanya dengan mendengar iklannya saja". Sedangkan bobot terendah sebesar 2,47 berada pada pernyataan "Pelanggan dapat langsung mengenali merek Sarimi hanya dengan melihat model/kemasannya".

Dari hasil penelitian Perceived quality (X2), keseluruhan berada dalam kategori cukup baik dengan pernyataan cukup setuju sebanyak $82.26 \%$, tidak setuju $5.80 \%$ dan sangat tidak setuju 4,94\% dengan rata-rata skor jawaban diperoleh sebesar 2,66 dimana berdasarkan interpretasi skor, maka rata-rata tersebut berada pada tingkatan cukup baik karena berada pada interval 2,60 - 3,39. Dengan bobot rata-rata tertinggi yaitu sebesar 2,92 berada pada pernyataan "PT. Indofood Sukses Makmur Tbk. memiliki pelayanan yang baik dan memuaskan bagi konsumen". Sedangkan bobot terendah sebesar 2,55 berada pada pernyataan "Mie instant Sarimi menggunakan bahan baku terbaik dan berkualitas" dan "Informasi petunjuk masak selalu tertera di bagian kemasan produk".

Dari hasil penelitian Brand Association (X3), secara keseluruhan responden yang menyatakan cukup setuju sebanyak $85 \%$, tidak setuju $9.74 \%$ dan sangat tidak setuju 5,26\% ratarata skor jawaban diperoleh sebesar 2,60 dimana berdasarkan interpretasi skor, maka rata-rata tersebut berada pada tingkatan cukup baik karena berada pada interval 2,60 - 3,39. Dengan bobot rata-rata tertinggi yaitu sebesar 2,69 berada pada pernyataan " Harga yang ditawarkan kepada pelanggan terjangkau dan sesuai dengan kualitas yang didapatkan". Sedangkan bobot rata-rata terendah berada pada pernyataan "Mie instant Sarimi memiliki varian rasa yang bermacammacam sehingga dapat memenuhi keinginan saya" dengan bobot sebesar 2,54.
Dari hasil penelitian Brand Loyalty (X4), secara keseluruhan responden yang menyatakan cukup setuju sebanyak $91.47 \%$, tidak setuju $5.78 \%$ dan sangat tidak setuju $2,75 \%$ dengan nilai rata-rata 2.77 , artinya responden cukup baik dalam hal loyalitas terhadap pembelian mie instant merek Sarimi, karena berada pada interval 2,60 - 3,39. Bobot tertinggi berada pada pernyataan "Kepuasan saya terhadap mie Sarimi membuat saya cenderung untuk merekomendasikan kepada orang lain" dengan bobot sebesar 2,84. Sedangkan bobot terendah berada pada pernyataan "Saya terbiasa membeli mie instant merek Sarimi" dengan bobot sebesar 2,69 .

Dari hasil penelitian terhadap variabel keputusan pembelian (Y), responden menyatakan pembelian pernyataan cukup setuju sebanyak $88.06 \%$, tidak setuju $6.35 \%$ dan sangat tidak setuju 5,59\% dengan nilai rata-rata 2.62. Bobot tertinggi dengan pernyataan "Dengan berbagai macam pertimbangan saya tidak ragu-ragu memilih mie instant Sarimi" dalam hal pertimbangan dalam membeli memiliki nilai rata-rata tertinggi yaitu 2,69, dimana konsumen Supermarket $\mathrm{X}$ Bandung beranggapan bahwa konsumen tidak akan ragu-ragu dalam melalukan pembelian mie instant Sarimi dengan bermacammacam pertimbangan yang ada. Sedangkan bobot terendah ada pada pernyataan "Saat saya menginginkan mie instant, saya pasti akan membeli mie instant merek Sarimi" dalam indikator kemantapan membeli memiliki nilai rata-rata terendahyaitu sebesar 2,50, dimana konsumen Supermarket X Bandung beranggapan bahwa konsumen belum pasti akan membeli mie instant Sarimi pada saat konsumen menginginkan mie instant.

Tabel 4 Koefisien Kolerasi (R) Model Summary

\begin{tabular}{ccccc}
\hline Model & $\mathrm{R}$ & $\begin{array}{c}\mathrm{R} \\
\text { Square }\end{array}$ & $\begin{array}{c}\text { Adjusted } \\
\text { R Square }\end{array}$ & $\begin{array}{c}\text { Std. Error of } \\
\text { The Estimate }\end{array}$ \\
\hline 1 & 0,869 & 0,755 & 0,745 & 0,84514 \\
\hline
\end{tabular}

Sumber: Data terolah

Hasil perhitungan dengan menggunakan program SPSS dapat diketahui bahwa nilai $\mathrm{R}$ sebesar 0.869.Berdasarkan tabel interpretasi koefisien korelasi, nilai tersebut termasuk dalam kategori sangat kuat.Maka dapat disimpulkan bahwa variabel terikat dengan seluruh variabel bebas 
secara bersama-sama memiliki pengaruh yang sangat kuat yaitu sebesar $86.9 \%$. Dan sisanya sebesar $13.1 \%$ dipengaruhi faktor lain yang tidak diteliti dalam meningkatkan keputusan pembelian.

\section{PENGUJIAN HIPOTESIS SECARA PARSIAL (Uji t)}

Untuk menghitung $t_{\text {tabel }}$ dipergunakan tabel distribusi t dengan $\mathrm{df}=100$ dan $\alpha=0.05$. Maka diperoleh $\mathrm{t}_{\text {tabel }}=1$ 1.66. Dari hasil perhitungan menunjukkan $\mathrm{t}_{\text {hitung }}$ lebih besar daripada $\mathrm{T}_{\text {tabel }}$ yaitu $\mathrm{t}_{\text {hitung }}=5.7>1.66$. Berdasarkan hasil perhitungan diatas $t_{\text {hitung }}>t_{\text {tabel }}$ bahwa hipotesis yang penulis buat dapat diterima, artinya hipotesis penulis terdukung oleh fakta-fakta di lapangan. Mengacu kepada perhitungan di atas, $\mathrm{t}_{\text {hitung }}$ sebesar 5.7 berada pada daerah penolakan $\mathrm{H}_{0}$, dengan demikian hipotesis yang penulis ajukan, yaitu: "Brand Awareness berpengaruh signifikan terhadap keputusan pembelian", dapat diterima.

Sedangkan untuk variabel perceived quality, dari hasil perhitungan menunjukkan $\mathrm{t}_{\text {hitung }}$ lebih besar daripada $\mathrm{T}_{\text {tabel }}$ yaitu $\mathrm{t}_{\text {hitung }}=$ 15.14>1.66. Berdasarkan hasil perhitungan diatas $t_{\text {hitung }}>\mathrm{t}_{\text {tabel }}$ bahwa hipotesis yang penulis buat dapat diterima, artinya hipotesis penulis terdukung oleh fakta-fakta dilapangan. Mengacu kepada perhitungan diatas, $t_{\text {hitung }}$ sebesar 15.14 berada pada daerah penolakan $\mathrm{H}_{0}$, dengan demikian hipotesis yang penulis ajukan, yaitu: "Perceived Quality berpengaruh signifikan terhadap keputusan pembelian". Dapat diterima.

Variabel brand associations, untuk menghitung $\mathrm{t}_{\text {tabel }}$ dipergunakan tabel distribusi $\mathrm{t}$ yang terdapat pada lampiran dengan $\mathrm{df}=100 \mathrm{dan}$ $\alpha=0.05$. Maka diperoleh $\mathrm{t}_{\text {tabel }}=1.66$. Dari hasil perhitungan menunjukkan $t_{\text {hitung }}$ lebih besar daripada $\mathrm{T}_{\text {tabel }}$ yaitu $\mathrm{t}_{\text {hitung }}=11.22>1.66$. Berdasarkan hasil perhitungan diatas $t_{\text {hitung }}$ $>t_{\text {tabel }}$ bahwa hipotesis yang penulis buat dapat diterima, artinya hipotesis penulis terdukung oleh fakta-fakta dilapangan. Mengacu kepada perhitungan diatas, $\mathrm{t}_{\text {hitung }}$ sebesar 11.22 berada pada daerah penolakan $\mathrm{H}_{0}$, dengan demikian hipotesis yang penulis ajukan, adalah: Brand Association berpengaruh signifikan terhadap keputusan pembelian" dapat diterima.

Variabel brand loyalty, untuk menghitung $t_{\text {tabel }}$ dipergunakan tabel distribusi $t$ yang terdapat pada lampiran dengan $\mathrm{df}=100$ dan $\alpha=0.05$. Maka diperoleh $\mathrm{t}_{\text {tabel }}=1.66$. Dari hasil perhitungan menunjukkan $t_{\text {hitung }}$ lebih besar daripada

$\mathrm{T}_{\text {tabel }}$

yaitu $\mathrm{t}_{\text {hitung }}$

$=3.41>1.66$. Berdasarkan hasil perhitungan diatas $t_{\text {hitung }}>\mathrm{t}_{\text {tabel }}$ bahwa hipotesis yang penulis buat dapat diterima, artinya hipotesis penulis terdukung oleh fakta-fakta dilapangan.Mengacu kepada perhitungan diatas, $t_{\text {hitung }}$ sebesar 3.41 berada pada daerah penolakan $\mathrm{H}_{0}$, dengan demikian hipotesis yang penulis ajukan, yaitu:

"Brand Loyalty berpengaruh signifikan terhadap keputusan pembelian" dapat diterima.

Untuk menganalisis pola hubungan kausal antar variabel dengan tujuan untuk mengetahui pengaruh antara Brand Awareness (X1), Perceived Quality (X2), Brand Association(X3), Brand Loyalty (X4) terhadap keputusan pembelian (Y), digunakan analisis korelasi dimana proses perhitungannya menggunakan alat bantu software SPSS 20 for Windows dan selanjutnya dilakukan perhitungan koefisien determinasi untuk mengetahui pengaruh masing-masing variabel bebas terhadap variabel terikat.Berdasarkan tabel korelas yang diperoleh, korelasi Brand Awareness (X1) terhadap keputusan pembelian $(\mathrm{Y})$ yaitu sebesar 0.499. Kesimpulan statistiknya, terdapat hubungan yang positif dan searah antara Brand Awareness (X1), Perceived Quality (X2), Brand Associations (X3), dan Brand Loyalty (X4) terhadapkeputusan pembelian (Y). Untuk menghitung berapa besar pengaruh (kontribusi) yang diberikan secara keseluruhan dapat diketahui melalui koefisien determinasi $(K d)$, dengan rumus:

$$
K d=r_{s}^{2} \times 100 \%
$$

\section{ANALISIS REGRESI LINIER BERGANDA}

Hasil penelitian analisis pengaruh Brand Awareness, Perceived Quality, Brand Associations, dan Brand Loyalty Mie Instant Merek Sarimi terhadap Keputusan Pembelian di Supermarket Kota Bandung secara Simultan, maka perlu diuji melalui analisis regresi berganda, uji koefisien korelasi, uji koefisien determinasi dan pengujian hipotesis simultan (Uji F).persamaan regresi berikut:

$$
Y=-2.344+0.107 X_{1}+0.342 X_{2}+0.150 X_{3}+
$$

Penjelasan dari persamaan di atas adalah sebagai berikut:

a. Nilai konstanta bertanda negatif 2.344 yang menunjukkan apabila variabel Brand Awareness, Perceived Quality, Brand Association serta Brand Loyalty ada 
perubahan atau sama dengan 0 maka keputusan pembelian sebesar 2.344 tidak berpengaruh signifikan.

b. Variabel Brand Awareness memiliki koefisien regresi bertanda positif sebesar 0.107 hal ini berarti apabila Brand Awareness ditingkatkan setiap 1 satuan, maka akan meningkatkan keputusan pembelian sebesar 0.107 berpengaruh signifikan.

c. Variabel Perceived Quality memiliki koefisien regresi bertanda positif sebesar 0.342 hal ini berarti apabila Perceived Quality ditingkatkan setiap 1 satuan, maka akan meningkatkan keputusan pembelian sebesar 0.342 berpengaruh signifikan.

d. Variabel Brand Association memiliki koefisien regresi bertanda positif sebesar 0.150 hal ini berarti apabila Brand Association ditingkatkan setiap 1 satuan, maka akan meningkatkan keputusan pembelian sebesar 0.150 berpengaruh signifikan.

e. Variabel Brand Loyalty memiliki koefisien regresi bertanda positif sebesar 0.108 hal ini berarti apabila Brand Loyalty ditingkatkan setiap 1 satuan, maka akan meningkatkan keputusan pembelian sebesar 0.108 berpengaruh signifikan.

Uji $\mathrm{F}$ digunakan untuk menguji ada tidaknya pengaruh variabel-variabel independen terhadap variabel dependen secara simultan (bersamasama). Maka dari hasil perhitungan bahwa nilai $F_{\text {hitung }}(73,312)>F_{\text {tabel }}(2,46)$ maka $H_{0}$ ditolak dan $\mathrm{H}_{\mathrm{a}}$ diterima yang artinya secara simultan terdapat pengaruh yang signifikan secara bersama-sama (simultan) dari Brand Awareness, Perceived Quality, Brand Association dan Brand Loyalty mempunyai pengaruh yang signifikan terhadap keputusan pembelian.

\section{KESIMPULAN DAN SARAN KESIMPULAN}

Penelitian ini memperlihatkan hasil analisis pengaruh brand equity yang berisikan empat faktor yaitu brand awareness, perceived quality, brand association, dan brand loyalty terhadap keputusan pembelian mie instant di Supermarket di kota Bandung. Berdasarkan hasil penelitian dan pembahasannya maka dapat disimpulkan sebagai berikut: Berdasarkan hasil penelitian deskriptif variabel brand awareness, perceived quality, brand association, dan brand loyalty terhadap keputusan pembelian mie instant di Supermarket dikota Bandung yaitu:
1. Brand awareness secara keseluruhan sudah cukup baik dilakukan oleh mie instant, hal ini dapat dilihat dari hasil penelitian deskriptif dimana indikator unware of brand dan brand recall memiliki nilai rata-rata tertinggi yaitu sebesar 2,86, dimana konsumen Supermartket Bandung cukup menyadari keberadaan mie instant konsumen juga dapat langsung mengenali mie instant hanya dengan mendengar iklannya. Namun terdapat indikator brand awareness yang memiliki nilai rata-rata terendah yaitu brand recognition yaitu sebesar 2,47 , di mana masih banyak konsumen yang tidak dapat langsung mengenali keberadaan mie instant hanya dengan melihat warna kemasannya.

Perceived quality secara keseluruhan sudah cukup baik dilakukan oleh mie instant merek Sarimi ini. Berdasarkan hasil penelitian deskriptif indikator perceived quality yang memiliki nilai rata-rata tertinggi adalah indikator fit and finish yaitu sebesar 2,92, dimana konsumen memiliki anggapan kalau PT Indofood Sukses Makmur Tbk. memiliki pelayanan yang baik dan memuaskan bagi konsumen. Sedangkan indikator perceived quality dengan nilai rata-rata terendah yaitu serviceability dan performance dengan nilai 2,55, dimana konsumen memiliki anggapan kalau mie instant Sarimi bahan baku yang digunakan belum memiliki kualitas yang baik dan informasi pentunjuk masak juga tidak selalu tertera pada kemasan mie instant Sarimi.

Brand association secara keseluruhan sudah cukup baik dilakukan oleh mie instant merek Sarimi ini. Berdasarkan hasil penelitian deskriptif, indikator brand association yaitu atribut (atribute) memiliki nilai rata-rata tertinggi yaitu sebesar 2,69, dimana konsumen Supermarket X Bandung beranggapan bahwa harga mie instant yang ditawarkan kepada para konsumen cukup terjangkau dan sesuai dengan kualitas yang didapatan. Sedangkan indikator manfaat (benefit) memiliki nilai rata-rata terendah sebesar yaitu sebesar 2,54, dimana konsumen Supermarket Bandung beranggapan kalau mie instant Sarimi memiliki varian rasa yang kurang beraneka ragam sehingga kurang bisa memenuhi keinginan konsumen.

Brand loyalty secara keseluruhan sudah baik dilakukan oleh mie instant merek Sarimi ini. Berdasarkan hasil penelitian deskriptif, indikator brand loyalty yaitu measuring 
satisfaction memiliki nilai rata-rata tertinggi yaitu 2,84, dimana konsumen Supermarket $\mathrm{X}$ Bandung beranggapan bahwa kepuasan yang telah dirasakan akan cenderung membuat konsumen untuk merekomendasikan mie instant Sarimi kepada orang lain. Sedangkan indikator brand loyalty yang memiliki nilai rata-rata terendah yaitu behaviour measures sebesar 2,69, dimana konsumen Supermarket $\mathrm{x}$ Bandung masih cukup banyak yang belum terbiasa untuk membeli mie instant Sarimi. Keputusan pembelian dengan indikator pertimbangan dalam membeli memiliki nilai rata-rata tertinggi yaitu 2,69 , di mana konsumen Supermarket $\mathrm{X}$ Bandung beranggapan bahwa konsumen tidak akan ragu-ragu dalam melalukan pembelian mie instant Sarimi dengan bermacam-macam pertimbangan yang ada. Sedangkan indikator kemantapan membeli memiliki nilai rata-rata terendah yaitu sebesar 2,50, di mana konsumen Supermarket $\mathrm{X}$ Bandung beranggapan bahwa konsumen belum pasti akan membeli mie instant Sarimi pada saat konsumen menginginkan mie instant. Sedangkan berdasarkan hasil analisis pengaruh brand awareness, perceived quality, brand association, dan brand loyalty terhadap keputusan pembelian mie instant merek Sarimi di Supermarket $X$ di kota Bandung, yaitu:

2. Berdasarkan pengujian koefisien determinasi (Kd) adalah sebesar $\mathbf{2 4 . 9 \%}$ mempunyai arti bahwa pengaruh Brand Awareness (X1) terhadap keputusan pembelian (Y)adalah sebesar 24.9\% Sedangkan sisanya sebesar 75.1\% dipengaruhi oleh variabel lain yang tidak diteliti pada penelitian ini.

3. Berdasarkan pengujian analisis koefisien determinasi (Kd) adalah sebesar $\mathbf{7 0 . 0 6 \%}$ mempunyai arti bahwa pengaruh Perceived Quality (X2) terhadap keputusan pembelian (Y)adalah sebesar 70.06\% Sedangkan sisanya sebesar 29.94\% dipengaruhi oleh variabel lain yang tidak diteliti pada penelitian ini.

4. Berdasarkan pengujian analisis koefisien determinasi adalah sebesar $\mathbf{5 6 . 7 \%}$ mempunyai arti bahwa pengaruh Brand Association (X3) terhadap keputusan pembelian (Y)adalah sebesar $\mathbf{5 6 . 7 \%}$ Sedangkan sisanya sebesar $\mathbf{4 3 . 3 \%}$ dipengaruhi oleh variabel lain yang tidak diteliti pada penelitian ini.

5. Berdasarkan pengujian analisis Koefisien Determinasi (Kd) adalah sebesar $\mathbf{9 . 6 7 \%}$ mempunyai arti bahwa pengaruh Brand Loyalty (X4) terhadap keputusan pembelian (Y)adalah sebesar $\mathbf{9 . 6 7 \%}$ Sedangkan sisanya sebesar $\mathbf{9 0 . 3 3 \%}$ dipengaruhi oleh variabel lain yang tidak diteliti pada penelitian ini.

6. Secara simultan, hasil perhitungan koefisien korelasi berganda (R)brand awareness, perceived quality, brand association dan brand loyalty memiliki keeratan hubungan yang kuat dengan keputusan pembelian. Hasil koefisien determinasi dan hasil uji hipotesis secara simultan menunjukkan bahwa terdapat pengaruh yang signifikan secara bersamasama (simultan) dari variabel brand awareness, perceived quality, brand association dan brand loyalty mempunyai pengaruh yang signifikan terhadap keputusan pembelian.

Mengacu kepada perhitungan yang

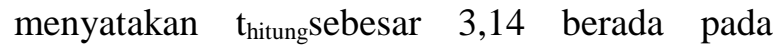
daerahpenolakan $\mathrm{H}_{0}$ dengan demikian hipotesis yang penulis ajukan, yaitu: "Brand Loyalty berpengaruh signifikan terhadap keputusan pembelian". Maka dapat ditarik kesimpulan bahwa secara bersama-sama seluruh faktor di atas mempunyai pengaruh yang signifikan terhadap keputusan pembelian, sarimi yang bukan top brand mie instant memiliki hal tersebut.

\section{SARAN}

Setelah mengkaji hasil penelitian ini, maka yang dapat penulis ajukan saran adalah sebagai berikut: Brand equity dengan faktor brand awareness, perceived quality, brand association, dan brand loyalty jelas memiliki pengaruh terhadap keputusan pembelian mie instant merek Sarimi yang dilakukan oleh konsumen Supermarket $x$ di Kota Bandung. Secara keseluruhan faktor-faktor yang brand equity yang dimiliki sudah cukup baik, namun dalam hal ini masih terdapat beberapa hal yang perlu diperbaiki oleh mie instant merek Sarimi agar brand equity yang dimiliki semakin kuat. Faktor brand awareness mie instant Sarimi yang masih perlu diperbaiki adalah brand recognition-nya, dimana mie instant Sarimi perlu memperbaiki desain/model kemasan agar terlihat lebih berbeda dibandingkan dengan mie instant lainnya sehingga konsumen dapat langsung membedakan dan mengenali kemasan mie instant Sarimi hanya dengan melihat kemasannya saja.

Faktor perceived quality, pada faktor ini yang masih perlu diperbaiki adalah dari sisi 
serviceability dan performance. hal-hal yang dapat diperbaiki untuk meningkatkan kualitas mie instant Sarimi yaitu penggunaan bahan baku yang lebih baik sehingga berpengaruh terhadap ketahanlamaan produk dipasar (tidak cepat kadaluarsa), memberikan informasi petunjuk penyajian yang lebih jelas agar memudahkan konsumen dalam mengkonsumsi, dan menambah varian rasa yang lebih banyak lagi agar dapat memenuhi keinginan konsumen dalam mengkonsumsi mie instant.

1. Faktor brand association yang masih perlu diperbaiki adalah dari sisi manfaat (benefit) yang diberikan bagi konsumen. Dalam hal ini yang bisa dilakukan untuk meningkatkan manfaat (benefit) mie instant Sarimi yaitu dengan menambah dan berinovasi berbagai macam varian rasa sehingga dapat memenuhi keinginan konsumen.

2. Faktor brand loyalty yang masih perlu diperbaiki adalah dari sisi behaviour measures dimana mie instant Sarimi harus bisa menciptakan rasa keterbiasaan bagi konsumen untuk membeli mie instant Sarimi dibandingkan dengan mie instant merek lainnya. Misalnya dengan cara pendistribusian mie instant Sarimi yang lebih banyak dan lebih meluas lagi sehingga konsumen lebih terbiasa melihat dan menemukan mie instant Sarimi di pasaran.

3. Sedangkan untuk keputusan pembelian, masih terdapat kekurangan dalam hal kemantapan konsumen untuk membeli mie instant Sarimi. Kemantapan konsumen dalam melakukan pembelian dapat ditingkatkan dengan cara mie instant Sarimi memperbaiki beberapa hal yang telah penulis kemukakan pada poin-poin sebelumnya dalam untuk meningkatkan brand equity mie instant merek Sarimi yang nantinya akan berpengaruh terhadap keputusan pembelian konsumen.

Penelitian dapat dikembangkan dengan meneliti pengaruh variabel-variabel lain yang belum diteliti yang mempengaruhi keputusan pembelian.

\section{REFERENSI}

Aker, A.D. (2009). Managing brand equity. New York: Simon and Schuster.

Aker, A.D. (2009). Strategic market management. John Wiley \& Sons, Inc.

Aker, A.D. (2009). Managing brand equity. New York: Simon and Schuster.

Aker, A.D. (2009). Strategic market management. John Wiley \& Sons, Inc.
Ferrinadewi, E. (2008). Merek dan psikologi konsumen, implikasi pada Strategi Pemasaran. Yogyakarta: Graha Ilmu.

Handayani, D. dkk. (2010). The official MIM academy coursebook brand operation. Jakarta: Esensi Erlangga Group.

Hermawan, A. (2009). Metode penelitian bisnis. Jakarta: Grasindo.

Kotler, P.K. (2010). Manajemen pemasaran. Jakarta: Erlangga.

Palupi, D.H. (2009). Merek - merek di puncak ekuitas.

Rangkuti, F. (2009). Strategi promosi yang kreatif dan analisis . Jakarta: PT. Gramedia Pustaka Utama.

Rangkuti, F. (2009). The power of brands teknik mengelola brand equity dan strategi pengembangan merek. Jakarta: PT Gramedia Pustaka Utama.

Schiffman, L. G., \& Kanuk, L. (2009). Persepsi kualitas customer Behaviour. New Jersey: Pearson Prentice Hall. 
Jurnal Manajemen Maranatha — Vol. 18 Nomor 2, Mei (2019) 